This last chapter will be of particular interest to all who, like readers of ORYX, are concerned about the rapid shrinkage of Britain's wild places. There are now fifteen reserves in all within the Park-five of them mountain and eight woodland, with two on the coast, comprising as wide a variety of habitat and as diversified a fauna and flora as can be found anywhere within our island. A short account is given of the work of the Nature Conservancy not only in selecting and establishing these reserves but in research on their ecology, on the composition of their soils, and on the grasses and other plants that grow on them, and in the various activities of the wardens. The book is well illustrated with monochrome and also nine colour plates, and with maps and diagrams. Appendices include lists, with notes, of the upland plants, the birds and the butterflies, and the names and addresses in North Wales of bodies concerned with conservation.

\title{
COLIN MATHESON
}

\section{Britain's Wildlife, Rarities and Introductions, by Richard} Fitter and John Leigh-Pemberton. Nicholas Kaye, $21 \mathrm{~s}$.

The series of attractive wildlife pictures by John Leigh-Pemberton which have appeared in the Midland Bank advertisements during the last two years have now been brought together in a book, with explanatory text by Richard Fitter, a foreword by HRH the Duke of Edinburgh and a preface by Peter Scott. No fewer than 76 species are included in the 35 paintings14 mammals, 51 birds, six fishes and five butterflies. Twenty-three of the paintings are of rarities and the remaining twelve of species which have been introduced to Britain, some of which, such as the rabbit, pheasant and little owl, have become familiar members of our fauna. The reproduction of the plates is excellent but it is somewhat confusing that the captions at the side of each picture are not printed opposite the species to which they refer in some plates such as that of the terns, necessitating reference to the text pages for clarification.

Richard Fitter's text provides a valuable up-to-date summary of the history and status of each spedies, brimful of information. His introduction is a lucid account of the factors which make for rarity or abundance in a species under present-day competition with man. This is a book that all who care for our wildlife and like beautiful things will wish to possess, and in buying it they are helping in a practical way to conserve Britain's wildlife, for royalties go to the British National Appeal of WWF.

\section{JOHN CLECG}

\section{The Way to the Mountains of the Moon, by Rennie Bere. Barker, 36s.}

Mr Bere's way was to join the Colonial Service in 1930 , get posted to Uganda, and keep withlin either sight or driving distance of the Ruwenzori until his retirement in 1960 . Given half a chance, or some sick leave, he was up in the mountains, climbing them, getting lost, noting the natural history, and generally being extremely content with some of Africa's remarkable assortment of high peaks. The book is a miscellaneous potpourri of reminiscences and fact. It is a kind of biography about geography, for neither Mr Bere's personal life and feelings nor the requirements of his job are ever mentioned, except in passing from peak to peak. One chapter is called "Flounderings in a mountain forest", and even the climbs are described in an off-hand manner, without much detail or time to build 
up suspense, and without the incidents maturing from anecdote into something grander. This work is best as a general introduction, not to the people but to the high ranges and natural history of the area, to the bizarre botany of the mountains of the moon.

Rennie Bere ended his time in Africa as Chief Warden of the Uganda National Parks. This was obviously a crowning happiness to his career, for the book implies that all three decades were of contentment with the final time at Mweya best of all-apart from those many scramblings uphill. His short book is written smoothly, the facts are affectionately recounted, and one wonders how the author can now bear to live at Bude, Cornwall. It fills even a reader with a desire to go back to those parts where he used to live.

ANTHONY SMITH

\section{The African Lion, by Mervyn Cowie. The African Elephant, by Rennie Bere. Barker, 21 s. each.}

Mervyn Cowie, formerly Director of Kenya National Parks, who has done more than anyone else to establish National Parks in Kenya, examines the lion's life history, foibles and fables. The first section of the book deals with the life history, the lion's place in the African scene and relationship with its prey, the animals that depend on it for food, those that fear it, and those, from the enormous elephant to the diminutive ratel, who fear it not. The second section concerns its relationship with man, from maneating to marauding, to lion men (and women) and witchcraft. In both sections the author very properly debunks a number of well-known "facts".

Rennie Bere, formerly Director and Chief Warden of Uganda National Parks, sets out the life history of the elephant in a similar manner, and manages to condense a wealth of information about his subject into a short and readable account, with many keen observations made by himself during his years of close association with elephants. He, too, disproves many a well-known "fact." I was pleased to see how much stress he puts on the thorny subject of population control and management of habitat if this delightful and interesting animal is to survive this modern age.

Both books are illustrated with excellent photographs in colour and black and white, and the elephant book is also enhanced by a very good reproduction of a David Shepherd painting. They are first-class value for readers of all ages and highly recommended.

\section{R. J. WHEATER}

\section{The Land and Wildlife of South America, by Marston Bates, and Tropical Asia, by S. Dillon Ripley. \\ Time-Life International, 32s. 6d. each.}

South America is a continent of immense wildlife variety and Marston Bates's book is a magnificent introduction to it, a masterpiece of lucid compression, beautifully illustrated and interesting from beginning to end. To many English people South America is just the Amazon. The OrinocoAmazon river basin is an enormous inland sea, gradually rising and turning into a huge freshwater river system. To this the inhabitants must accommodate themselves, and so we find skates and rays in the rivers, freshwater dolphins, and mammals which take readily to the water. When floods come, all life must swim, climb or perish.

In the continent's long period of insular isolation, until two or three 